\title{
A SURVEY OF ARCHIVES IN THE NETHERLANDS PERTAINING TO THE HISTORY OF THE NETHERLANDS ANTILLES
}

BY

\section{A. P. MeILINK-RoELOFSZ}

The Netherlands General State Archives (Algemeen Rijksarchief) at The Hague are divided into three sictions. The first section contains the Central Government records up to the year 1796, those of the Boards of the East India Company and the two West India Companies, and those of the colonial administrations overseas, as far as these have been transferred to the Netherlands.

The West India Company's first charter dates from 1621, whereas Curaçao was not conquered by the Lutch until 1634. For the earlier period of the colony's history it is thus necessary to resort to the First West India Company's ar$\mathrm{ch}$ ives (archief van de Eerste West-Indische Compagnie), the greater part of which have, however, been lost.

When J. ROMEYN BRODHEAD was makirg extensive researches for the publication of his "History of the S ate of New York" (1855) he came - on the basis of official information - to the conclusion that these First West India Company archives had been sold for scrap paper in 1821. This he reported to his Government.

$$
\therefore
$$

Later authors, such as HAMElberg and L'Honoré NABER, re-iterated this fact and exposed it as a sample of 19th century vandalism. They were wrong, however, for old inventories saved from the end of the 18th and earlier 19th centuries clearly indicate that most of the First Company's archives had already been lost at that stag? All the papers destroyed in 1821 were dated later than 1674. They were concerned for the most part with financial affairs. It is probable that a large portion of the archives of the 
first West India Company was already done away with in 1674 on the occasion of the Company's reorganisation. The remainder still in existence today has been catalogued in a manuscript inventory containing 80 numbers.

The Central Board of the W.I. Company known as Heren XIX (the nineteen trustees consisting of representatives of the five confederated Chambers) kept records of their meetings, both secret and ordinary ones. Of these proceedings only a few years are still extant, those for the period 1623-1624 and 1629-1645. The same applies to those of the Amsterdam Chamber, which cover the periods $1635-1636$ and 1668-1674.

The surviving proceedings of the Zeeland Chamber meetings are more comprehensive. With the exception of the years 1646-1658 they form a consecutive series between 1626 and 1674 .

These 13 volumes, however, have no indices.

Any research concerning the Netherlands Antilles will thus first necessitate the sifting of the proceedings, then a search through the meagre remainders of other series, such as the copybooks of outgoing letters of the Nineteen, 1629-1657 (3 nos.) or the proceedings of subcommittees set up by the Nineteen (the so-called besognes), 1645-1665 (4 nos.).

The Zeeland Chamber archives contain, moreover, a few miscellaneous papers: reports, descriptions, commissionings, charters for new colonies to be settled, agreements, journals, etc., part of which also contain data on the Caribbean area.

A letter about the conquest of Curaçao on 27 August 1634 by Pierre LE GRAND has been preserved among the Amsterdam Chamber papers.

In addition to the archives of the First West India Company, other papers will require to be consulted, in order to cover the first period of colonization, in particular those of the S ates General, which had secured rather wide powers according to the terms of the charter.

A new Chartered Company was formed in 1674. It is more accurate, however, to regard this change as a reorganisation of the existing Company, since the only important modification was the reduction of the membership of the Central Board from nineteen to ten members. Nine of these ten were representatives of the several Chambers, as the Nineteen had been, the tenth member being appointed by the States General.

Of the Second West India Company's archives (archief van de Tweede West-Indische Compagnie) - which are far more complete than those of its predecessor - a manuscript inventory is bound in the same volume which contains the inventory of the first Company. This inventory was compiled by $\mathrm{A}$. 
Telting early in the present century. Though useful, it does not contain any data on the organisation and administration of the Company nor on the archives themselves, such as one is accustomed to expect nowadays.

The papers of the Second W.I.C. are likewise divided into subsections: those originating from the Board of Heren $X$ and those from the Chambers.

To some extent these sub-sections contain the same (i.e. duplicate) papers. This applies especially to letters from the colonies to the metropolis, of which as many copies were despatched as there were Chambers.

Since by reason of this fact references to the Antilles papers were included in the inventory under several different headings, TELTING published a survey of the sources of the history of the Netherlands Antilles in the 1st and 4th annual report of the Historical Society at Curaçao ${ }^{1}$ ).

In the Heren $\mathrm{X}$ sub-section the most important series is that of the proceedings from 1701 to 1791 (22 nos.).

The Zeeland Chamber papers contain an additional series beginning with 1674 to 1791 (20 nos.). Both these series have indices and chronological registers.

In the Heren $X$ sub-section the secret proceedings for the periods 1675-1700 and 1663-1789 (2 nos.)have been preserved. Important also are the copy-books of letters to America among which those to Curaçao are to be found, 1691-1791 (9 nos., with index till 1779). Apart from these, drafts are also extant covering the periods $1687-1690$ and 1722 1784 (10 nos., without tables).

Letters from Curaçao exist in 13 nos., 1700-1788, with tables; also, resolutions and sentences for the years 1704-1758 (6 nos.) and papers on several law cases, 1721-1792 (4 nos.). Particulars of individuals are provided by military pay-books, $1675-1792$ (6 nos. with indices) and by the lists of family and capitation taxes, 1786-1791 (1 no.).

Some papers on miscellaneous subjects prove to be of more general importance, such as those pertaining to the fortification of the island (1737-1743) while a report by the naval commander, SchriJver, on conditions on the island dates from 1737.

Letters addressed to the Heren $\mathrm{X}$ from the island of St. Eustatius have also been preserved for the years 1697-1778 (6 nos.) with tables of contents till 1767. Mention might also be made of the papers concerning the purchase by the W.I.C. of the isles of Saba and St. Eustatius in 16811683 , and of those concerning the transfer of Saba and St. Eustatius into the custody of the French in 1784; a report made to the Stadhouder

1) A. Telting: Bronnen voor de Geschiedenis van de Nederlandsche Antillen in het Rijksarchief te 's-Gravenhage. Jaarlijksch verslag van het Geschied-, Taal-, Land-en Volkenkundig Genootschap gevestigd te Willemstad, Curaf̧ao, I and 4, Amsterdam, 1897 and 1900. 
in 1791 on St. Eustatius, St. Martin and Saba and "observations regarding the commerce of the islands of Curaçao, St. Eustatius, St. Martin and Saba" (after 1788).

The same division has been made as regards the papers of the Amsterdam and Zeeland Chambers. The Amsterdam papers include proceedings for the period 1674-1791 (117 nos., with tables), secret records, 1701-1750 (1 no.), and copy-books of letters to America, 1675-1791 (12 nos., with tables till 1779). Another series contains letters to Curaçao 1773-1786 (4 nos.) and some drafts, 1687-1791 (2 nos.) Also letters and papers from Curaçao, 1700-1791 (51 nos., the majority with tables). A second series including the same documents 1732-1794 (13 nos., the majority with tables). A separate register of secret letters was also kept during the period 1680-1689.

Apart from a few letters and papers from St. Eustatius dating from the 17 th century $(1666,1679,1680,1686)$ the consecutive series, also including letters from St. Martin, starts with 1722 and extends as far as 1791 (20 nos., with tables). A second series contains letters from St. Eustatius and St. Martin 1723-1779 (4 nos.). One separate paper may be mentioned here in connection with the American War of Independence, i.e. a deduction and memoir of JoHANNES DE GRAAFF, the commander of St. Eustatius, 1777-1779.

As regards the Zeeland Chamber, the archives contain proceedings for the period 1674-1791 (76 nos., with chronological registers, tabl ss of contents etc., 27 nos.). Secret resolutions have been preserved for the period 1758-1777 only (1 no.); further, instructions, 1675-1798 (4 nos., with tables); copy-books of foreign letters, 1675-1791 (9 nos.); letters from the Amsterdam Chamber to Curaçao, 1773-1789; idem from Curaçao to the Zeeland Chamber 1700-1791 (31 nos.). Most of these are provided with tables. Letters to St. Eustatius are extant for the period 1773-1791 from the Amsterdam Chamber and the Chamber of the Maas (Meuse) i.e. Rotterdam (1 no.). Letters were received from St. Eustatius and the other islands during the period 1688-1791 (17 nos.), the series showing hiatuses between 1715 and 1717 , and between 1770 and 1780 . The registers contain tables of contents. Some pay-books originating from St. Eustatius have also been preserved for the period 1726-1779 (5 nos.).

The archives of the Chamber of the Maas only contain letters and papers from Curaçao, St. Martin and St. Eustatius, 1701-1723 (23 nos.); 1774-1791 St. Eustatius, St. Martin (7 nos.).

Only a few papers on special subjects concerning St. Martin have been preserved in the archives of the second W.I. Company, for instance a plan for purchasing the French half of St. Martin for the Dutch W.I. Company and documents concerning the delimitation of the boundary between the two zones of the island, 1748-1763.

A number of papers, mostly from the 18th century, concerning the Antilles may be found in a collection known as W e s t I ndian M iscellania (Verspreide West-Indische stukken) which belorg for the greater part to the Second Company's archives, but which have not yet been incorporated (manuscript catalogue of 1410 numbers, arranged topographically). 
The abolition of the Szcond West India Company in 1791 led to the settirg up of an interim Directorate for the West Indian Colonies. The Council for the Colonies in the We st In dies (Raad der koloniēn in West-Indië) brgan its activitiesin 1792. The a r c hives of bot h Directorate a n d C o u n c il (archief van directie en Raad) are d.scribed in a manuscript catalogue (190 nos.)

Similar papers are available for the Council's period of office (up to 1795 ) as for the W.I. Company: the proceedings of the Central Authority (22 nos.) and the letters to and from Curaçao ( 2 nos.). The series of pay-books relating to Curaçao is also continued ( 2 nos.); letters to and from St. Eustatius and St. Martin are contained in 7 nos., only some of which possess tables of contents.

Among the separate papers there are some concerned with the shipping traffic to the islands. This archival group also contains a report on the isle of Bonaire, dated 1793.

The former Chambers continued to exist as departments of the new administration. Papers for Amsterdam and Zeeland have been preserved, such as the Amsterdam proceedings (4 nos. and tables of contents), Zeeland proceedings (6 nos.), outgoing letters, Amsterdam (4 nos. and a table of contents) and Zeeland ( 3 nos. and tables of contents), incoming letters, Amsterdam (1 no.) and Zeeland ( 2 nos.).

As has already been stated, the archives mentioned so far belong to the first section of the General S ate Archives held at the Hague, whereas the archives we shall now proceed to treat belong to the second section, i.e. the Central Government records subsequent to $1795 / 1796$.

During the "French period" from 1795 to 1813 , when the Netherlands were under French influence the West-Indian colonies were administered in the Netherlands from $1795-1801$ by the Committee for the Affairs of the Colonies and Possessions on the Guinea Coast and i n A m e r i c a (Comité tot de zaken van de koloniën en bezittingen op de kust van Guinee en in Amerika).

The Committee's archives are listed in a provisional manuscript catalogue (247 nos.). Its proceedings (draft, secret and fair copies) with indices and appendices form the backbone of this collection for the whole period up till 1800 (41 nos.). These archives also contain outgoing letters to Curaçao, St. Eustatius and St. Martin for the period 1795-1800 (3 nos. with indices).

The reports of the departments of "policy" (i.e. home affairs) and justice, of militia and defence and of commerce and finance (all with index), and the petitions received, may all contain data concerning the history of the Antilles, but this is especially the case with 2 numbers of 
missives and appendices from Curaçao (1796-1802) the journals dispatched from the island between 1795 and 1798 (3 nos.), and the Accountant-General (boekhouder-generaal) 's missives with appendices and journals, 1796-1798 (1 no.). There is even one volume of the political proceedirgs of the Governor and Councillors of Curaçao, dispatched from the island.

Documents concerning the island's defence and a list of plantations and properties sold on April 6, 1795, show the repercussion in the Caribbean area of events in Europe.

A general roll of persons having paid the $4 \% \operatorname{tax}$ (25th penny) according to a notification dated May 9, 1797 may be of importance as regards the history of families. There is also a list of functionaries in office on Curaçao, St. Eustatius and St. Martin in 1796. As regards the two latter islands the most important documents are 2 volumes of missives plus appendices, with index; while as to St. Martin itself, besides a memoir on the defence of the island, most of the documents preserved are of a financial nature.

Proceedings with appendices are extant for the departments of Amsterdam (19 nos.) and Zeeland (5 nos.) both with indices; further a copy-book of outgoing missives from Amsterdam, covering the period 1796-1800 (with index); from Zeeland drafts of letters 1795-1801 (1 no.) and petitions $1795-1800$, with index (1 no.).

The Council for Possessions and Establish$\mathrm{m}$ e $\mathrm{n} \mathrm{t} \mathrm{s}$ in A m e ri c (Raad der Amerikaanse bezittingen en etablissementen) came into being on January 5, 1801 and functioned till July 1806.

The manuscript inventory of its archives (265 nos.) is provisionally arranged in the same way: proceedings $(57$ nos. containing ordinary and secret proceedings, appendices and indices), copy-books of letters to and from the colonies, e.g. from Curaçao 1801-1807 (4 nos.). The journals of the Governor of Curaçao for the period 1804-1806 (5 nos., with appendices) and the proceedings of the civil council meetings of the Governor and Council of Curaçao during the period 1800-1803, have also been despatched.

Separate papers concerning Curaçao of which mention may be made are those on the surrender of the islands to the British in 1800 ( 2 nos.), the rolls of military ofticers stationed with the troops in Curaçao 17951804 ( 2 nos.), petitions to the Staatsbewind (State Government, i.e. the central authority in the Netherlands) on Curaçao affairs, matters submitted to the Council of American Possessions for advice and reply (1804). - In addition to these documents, the Council's secretary, J. C. VAN DER KEMP, collected a number of papers concerning Curaçao and Surinam (Dutch Guiana), referring, for instance, to the activities of the French agents at Guadeloupe aimed at Curaçao 1797-1801, to the British attack in 1804 and further a roll of Company officials stationed on Curaçao during the same period.

Letters from St. Eustatius with appendices have been preserved for the period 1802-1805 (1 no.); and journals for the period 1802-1803 (1 no.); likewise for St. Martin, 1800-1806 (2 nos. with tables of contents). 
Correspondence between the Governor and the Home Council between 1803 and 1806 ( 4 nos.) is also to be found in these archives. For the rest, papers concerning St. Martin deal mostly with financial and shipping matters, apart from a description of the island, dating from 1805 .

Information on the troops in the West Indies is contained in Council papers e.g. officers' rolls and pay-books, with alphabetical register.

The Amsterdam department of the Council is i.a. represented by a copybook of letters from 1801 to 1803 (2 nos.), and by reports of the Council's commissioner 1803-1806, with tables (7 nos.).

The Council for the American Possessions was succeeded in July 1806 by the M in is t ry of Trade and Colonies (Ministerie van Koophandel en Koloniën) which functioned until December 31, 1807, when its activities were taken over by the $\mathrm{M}$ inistry of $\mathrm{Naval}$ and $\mathrm{Colonial} \mathrm{Affairs}\left(\mathrm{Mi}_{-}\right.$ nisterie van Marine en Koloniën) the activities of which came to an end on the incorporation of the Kingdom of Holland into the French Empire in 1810.

The records of these Ministries (provisional manuscript inventory, 97 nos.) contain the Ministers' written reports (verbalen) with appendices for the period 1806-1807 (4 nos.). Extracts only exist for the years 18081810 (3 nos.). The archives also embody ministerial orders, 1806-1810, copy-books of ministerial missives to Curaçao, 1806-1807, to St. Eustatius, 1806-1809 and to St. Martin, 1806-1810, all three with tables of contents ( 3 nos.) and a copy-book of outgoing secret missives 1804 1807; reports and letters of the Head of the section for West-Indian affairs 1806-1807; letters with appendices from St. Eustatius, 1807 (1 no.), from St. Martin and Saba, 1807-1809 (5 nos.); letters to St. Eustatius, St. Martin and Saba 1809-1810. Pay-books have been preserved from Curaçao, commencing with 1802 (1 no.), and from St. Eustatius and St. Martin, 1802-1810 (2 nos.), with alphabetical registers.

Curaçao's conquest by the English in 1807 gave rise to a number of papers concerning accounting, fortifications, officials, civil and military. Also some documents are extant concerning the swearing of the oath of loyalty to the new sovereign in the Netherlands, King Lours NAPOLEON, by officials in the West Indies (1806-1808). As regards St. Martin, apart from a few financial documents there exists also an account by a former Governor of a British attack on the island in 1809 .

Some general memoranda on the West-Indian Possessions dating from 1806 and 1807 are contained in the Ministry's records. No papers exist in the Netherlands concerning the central administration of the Dutch colonies during the period of incorporation in the French Empire

After the inauguration of the United Kingdom of the Netherlands, data on the Netherlands Antilles are to be found in the Ancient Archives of the Ministry of Colonial A f f a r a f ter 1813 (oud archief van het Ministerie van Koloniën na I8I3) in which much correspondence with, and concerning, these islands has been deposited. 
These Archives, to be found in the General State Archives at the Hague, are arranged in chronological order and may be easily consulted by means of the classified indices and the alphabetical annual indices.

Apart from these records, other documents of particular importance but poorly inventoried are as follows: The Proceedings of the High Council of the West Indian Colonies, 1828-1829 (1 no.); reports on the West Indies in general, 1815-1823 ( 8 nos.); the dispatches of the Governor-General of the West-Indian Possessions, 1830-1843 (46 nos.); Royal Decrees and Ministerial Decisions on the West Indies in general, 1814-1824 (2 nos.).

As regards Curaçao these archives contain the journal of the Governor-General of that island and of the dependencies of Bonaire and Aruba, 1816-1828 (16 nos.); idem, in duplicate, 1817-1828 (23 nos.); the government journal 1830-1849 (78 nos.); proceedings of the Political Council, 1816-1827 (12 nos.), of the Court of Civil and Criminal Justice, 18251828 (1 no.); Royal and Ministerial Decrees concerning Curaçao, 18141828 (2 nos.); reports on Curaçao, 1816-1823 (8 nos.); letters, 1816$1829,1836-1845$ (19 nos.).

As regards St. Eustatius, St. Martin and Saba the archives contain the Governor's journal, 1817-1823 (7 nos.); the journal of the Commander of St. Martin and Saba, 1816-1828 (3 nos.) with duplicate copy, 18161819 (2 nos.); the journals of the Commander of St. Eustatius, Saba and St. Martin, 1828-1833 (20 nos.; for 1828 St. Eustatius and Saba only); reports on Saba, St. Eustatius and St. Martin, 1815-1824 (4 nos.); records of the Political Council 1817-1822 (2 nos.); records of the Court of Civil and Criminal Justice, 1820-1828 (1 no.); letters, 1816-1823 (13 nos.).

For St. Martin, the archives in question contain resolutions of the Commander and members of the Political Council, 1816-1821 (2 nos.); written reports of the President of the Political Council, 1823-1828 (1 no.); proceedings of the Court of Civil and Criminal Justice, 18231828 (1 no.); letters 1816, 1817 ( 1 no.).

Finally these archives include appointments of, and pensions to, civil servants, and ministers of religion in the East and West Indies and elsewhere, 1815-1819 (1 no.); lists of deceased Europeans in Surinam, Curaçao, St. Eustatius, St. Martin, 1816-1829 (1 no.) and reports on the slave trade, 1818-1823 (2 nos.).

Besides the sources mentioned the archives of the several Ministeries and those of the Kings' Cabinet (State Secretariat) may be consulted.

All the archives mentioned so far concern the successive administrations of the West-Indian Colonies IN THE NETHERLANDS.

Royal decrees of December 22, 1915 and July 7, 1919 ordered the archives accumulated in the West-Indian colonies up till 1828 to be transferred to the Netherlands. A comparison of these with old inventories, however, shows that many documents - especially those relating to the earlier periods - have been lost. 
The transferred archives till 1828 have been catalogued, inventories with detailed introductions prepared by R. BIJLSMA havirg been published in the annual reports on the Ancient S ate Archives for 1920 and $1924{ }^{1}$ ).

The transfer to the Hague of West Indian Archives covering the period 1828-1845 was ordered by a Royal decree of May 12, 1930. Manuscript inventories covering this period were prepared by E. HoogendiJK, an official of the General State Archives. A list of the West Indian Archives compiled by H. HARDENBERG $^{2}$ ) has been published as part of a survey of the General State Archives in 1953. The same sequence used in this survey is followed below.

One centralized administration covering all the Dutch West-Indian Possessions functioned for the period 1828 to 1845 only. Manuscript inventories exist of the archives of this central administration, i.e. the Archives of the Governor-General of the Dutch We st-I ndian Poss ess i o n s (archief van de Gouverneur-generaal der Nederlandse West Indische bezittingen) 1828-1845 (948 nos.) and the Archives of the High Councilassisting the Governor-General of the West-Indian Posses$\mathrm{s}$ i o $\mathrm{s}$ (archief van de aan de Gouverneur-generaal toegevoegde Hoge Raad over die bezittingen) 1828-1832 (17 nos.).

As regards the Antilles, the most important documents are the archives of the Governor-General, divided into two sections: G e $\mathrm{n}$ e $\mathrm{r}$ a 1 $\mathrm{S}$ e c r e t a ri a t (Algemene secretarie) 1828-1832 - known as Government Secretariat (Gouvernements-secretarie) between 1833 and $1845-$ and the Burea of the Military Command (Bureau van het militair commandement) 1828-1845. In 1845 the latter was suspended and incorporated into the Government Secretariat.

The records of the General (Government) Secretariat contain, inter alia, the journals of the Governor-General, 1828-1845 (63 nos.) with tables of contents after 1833; draft proceedings 1828-1829 (7 nos.); the incoming letters of the Ministry of the Colonies with appendices for the same period ( 37 nos.); incoming documents from various authorities (195 nos.); incoming letters from the Director of Curaçao, Bonaire and Aruba with appendices ( 33 nos.), idem from the Commander of St. Eustatius and Saba (3 nos.), and from the Government of St. Martin (5 nos.). There is also a diary, with index, covering these incoming documents $(83$ nos.). The archives in question also contain the journals, with appendix, of the Director of Curaçao, Bonaire and Aruba 18291845 received as incoming documents by the Governor-General (23 nos.);

$\left.{ }^{1}\right)$ R. Bijlsma: Het oud archief van Curaçao en onderhorige eilanden Bonaire en Aruba. Verslagen's Rijks oude Archieven I920, suppl. 1924. - De oude archieven van Sint Eustatius, Sint Martin en Saba. Verslagen 's Rijks oude Archieven 1924.

$\left.{ }^{2}\right)$ De Rijksarchieven in Nederland. Overzicht van de inhoud van de Rijksarchiefbewaarplaatsen. 
copies of the proceedings of the Court of Civil and Criminal Justice at Curaçao with copies of the appendices, 1830-1842 (7 nos.) and Curaçao ledgers, 1828-1842 (12 nos.).

Similar papers exist for the islands of St. Eustatius and St. Martin, i.e. journals of the Commander of St. Eustatius and Saba, 1829-1845 (5 nos.) copies of proceedings of the Court of Civil and Criminal Justice of St. Eustatius and Saba with copies of appendices, 1829-1840 (3 nos.), ledgers, 1830-1842 (7 nos.), journal of the President of the Political Council, in which was vested the civil and military authority (gezaghebber), of St. Martin, 1829-1844 (4 nos.), copies of proceedings of the Court of Civil and Criminal Justice of St. Martin with copies of appendices, 1829-1841 (3 nos.), ledgers of St. Martin 1828-1842 (11 nos.). A daily record 1830-1845 exist (33 nos.) of the volumes of copies of outgoing letters 1828-1845 (38 nos.), in which the letters 1830-1842 to the Government of Curaçao and dependencies (2 nos.), those to St. Eustatius and Saba (1 no.) and those to St. Martin (1 no.) are recorded separately. The archives of the Governor-General contain further segulations, instructions and notifications, some of them with tables of contents (6 nos.). Among papers kept separately is a copy of a report of the Governor-General for 1829, with appendices. Furthermore, documents on special subjects are classified topographically under separate headings.

Military affairs concerning the Antilles may be found recorded in the archives of the Military Bureau. Here are kept orders received from the Government (16 nos.); incoming documents from the Ministry of Colonial and Naval Affairs 1834-1844 (11 nos.); papers received concerning affairs of Navy Units stationed in the West-Indian Possessions and military affairs regarding Curaçao, St. Eustatius and Saba, 1828-1833 (6 nos.); papers received from Curaçao, 1834-1844 (11 nos.); idem from St. Eustatius and St. Martin, 1834-1844 (11 nos.); idem from the Commander (gezaghebber) of St. Eustatius and Saba, 1834-1840 (3 nos.) idem from St. Martin, 1837-1840 (1 no.); reports, petitions, etc., received 1828-1844 (65 nos.), idem concerning the Civil Guard (schutterij), 1829-1844 (16 nos.) and concerning persons sentenced 1827-1838 (11 nos.). A roll of these persons was kept from 1825 to 1837.

Most of these registers have tables of contents while a daily register exists of the papers received 1838-1845. The outward letters, 1825-1845, with tables, have also been preserved ( 25 nos.).

Among the documents on special subjects belonging to the military Bureau may be mentioned those on the fortification of Curaçao in 1827 and 1828 (1 no.).

Of the archives of the High Council of the Netherlands West-Indian Possessions only the proceedings, 1828-1832, with appendices, are extant (15 nos.), partly with tables of contents.

The Government Archives of the island of $C u r a c ̧ a$ (bestuursarchieven van het eiland Curaçao) for the period 1709-1828 contain the records of the D i r e c t o r a n d C o u n cillors (Directeur en Raden) 1709-1803, and those of the Provisional Government by Commissioners and Councillors (provisioneel bestuur door Com- 
missarissen en Raden) 1803-1804. The latter was an interim body, set up after Curaçao had been restored to the Netherlands by the British and functioning until the arrival of a Governor in September, 1804.

The inventory of these archives has been published in the report of the General State Archives for 1920 p. 617-629, with supplement in the report for 1924 p. 133-134 (254 nos. in all), and a supplement MS inventory (4 nos.).

In the beginning political and juridical affairs were not kept strictly distinct in these archives since the same Councillors dealt with both matters. After 1774, however, the Court Rolls and sentences with case papers were kept in separate series. With the exception of a few volumes of draft proceedings of the Director and Councillors and some fragments of registers on resolutions and sentences commencing in 1709 , the actual series of resolutions and sentences (including petitions received and case papers) commences with the year 1727 (67 nos., with tables from 1770 on). The first number contains no resolutions. Up to the year 1756 these volumes also contain the resolutions and sentences passed by the Commissioners for Puny Affairs.

In 1774 a separate series of Director's and Councillors' resolutions, together with incoming petitions, deeds of revision and of oaths concerning sentences began to be kept (38 nos. to 1804) and another series of Court Rolls and sentences pronounced by the Director and Councillors (48 nos., to 1804). The resolutions have tables of contents from 1783 on, the rolls from 1786. A series of draft proceedings of meetings of the Director and Councillors' (with appendices) begins with the year 1791 (12 nos.); idem regarding meetings of the councillors commissioned to hear pleas for 1789-1801 (3 nos.).

From 1790 onwards a separate series of petitions with decisions of the Director and Councillors was compiled (15 nos., with annual tables). A series of edicts, licences, passports, commissions, instructions and oaths taken by officials commences as from 1720 (66 nos., with tables from 1764 on), while there is also a register of outgoing documents leaving the Fiscal Councillor for 1792-1793.

On June 12, 1804 the Central Government (Staatsbewind) of the Batavian Republic laid down a new constitution for $\mathrm{Cu}-$ raçao and the dependent,isles. Supreme authority was vested in a Governor and a Politicál Council. A separate body was charged with the administration of justice, i.e. the Court of Civil and Criminal Justice, which Court obtained its own administrative office. Both Council and Court continued to exist after the capture of Curaçao by the British, a "Governor and Commander-in-Chief" being appointed as head of the Government.

Curaçao reverted to Dutch rule in 1816 on which occasion a new settlement regarding Government policy, the administration 
of justice, and trade and shipping for Curaçao and the dependent islands, was established by the Royal Decree of S ptember 14, 1815 (No. 58).

The supreme executive power was vested in a Governor-General who was at the same time the Commander-in-Chicf of the Army and Navy. In 1820 this title was simplified to that of Governor.

An inventory of the A r c hives of the Governor and the two Councils (archieven van de Gouverneur en de beide Raden) from 1804 till 1828 has been published in the General State Archives Report for 1920, p. 630-651, and for 1924, p. 134 (496 nos.). A manuscript supplement includes 74 additional numbers.

Government journals from 1816 on exist (12 nos. without index), regulations, instructions and ordinances since 1816 (16 nos. partly provided with tables), commissioners' instructions and instruments of oaths taken by officials from 1807 onwards (14 nos.), the Governor's notifications since 1816 ( 17 nos.) the copies being provided with indices), incoming petitions with decisions 1816-1829 and repertories till 1823 (13 nos.).

A file of requests for the inhumation of corpses 1823-1827 (with table) is interesting genealogically. The incoming documents include royal decrees laying down regulations and instructions, etc., 1814-1826 (4 nos.), and internal letters on civilian affairs 1809-1827 (12 nos.), letters on military affairs 1816-1827 (6 nos.), naval letters from 18171827 (4 nos.), letters from the Civic Guard, 1823-1827 (5 nos.), letters from Bonaire and Aruba (7 nos.), and from abroad (4 nos.). Repertories exist covering incoming decrees, letters, instructions and regulations for the period $1814-1827$ (5 nos.).

Reports on their administration received from the Boards of Orphans' Trustees have been preserved for 1808; the same from the councillorfiscal on prisoners, $1827-1828$.

Among the incoming papers of the Governor's archives (gouverneursarchief) are also the journals of the Commanders of Aruba, 1816-1826 (3 nos.) and of those of Bonaire, 1816-1827 (1 no.), while for this period publications and notifications from St. Eustatius are also present.

Apart from a number of documents received from the Ministry of the Colonies in 1815, all the letters from the Netherlands are missing.

Outgoing papers to the mothercountry are present for the period 1816-1820, while a repertory relating to these continues up to 1824 .

Incoming papers, 1816-1829 of which copies or duplicates had been sent to the Netherlands with outgoing letters, are kept separately (20 nos.).

Further papers preserved are outgoing civilian letters to the dependencies (11 nos. with repertories); outgoing military letters, till 1823 only (1 no., with an alphabetical register, 1816-1826). Only repertories are extant of the outgoing papers concerning the fortifications, 1826-1827 ( 1 no.) and of the outgoing letters to the Civic Guard, 1823-1824 (1 no.). Outgoing letters to the naval authorities, 1816-1827 (3 nos. with repertory), and outgoing letters to addresses abroad 1816-1825 (3 nos., with repertory) have been preserved. Of the outgoing letters to Bonaire and Aruba only a repertory is extant ( 2 nos.). 
A series of notifications regarding inheritances, etc. commences from 1807 ( 17 nos. with tables), deeds of manumission exist for the period 1808-1815 (5 nos. with tables); different kinds of warranty deeds, 18071816, refer to the transport of passengers (26 nos.).

These archives contain moreover reports, verbatim and others, bills of lading, claims and certificates, documents concerning inheritances (1817-1829 with table), also statements of colonial revenues and church revenues, $1826-1827$.

News items concerning the revolution in Venezuela derived from the Caracas daily papers have been preserved 1817-1819; and a number of papers on geological and mineralogical research regarding the soil of Curaçao, Bonaire and Aruba dated 1827.

Documents of the Political Council (Politieke Raad) begin in 1804 in which year a series of council meeting proceedings was begun (25 nos.). The same applies to petitions received, decisions on these, notifications regarding inheritances, etc., licences, passports, etc. (68 nos.). A series of letters of manumission starts from 1816 (11 nos.). Almost all series contain tables.

Proceedings of the Court of Civil and Criminal Justice (Raad van Civiele en Criminele Justitie) begin with 1805 (24 nos. with tables). Incoming documents and drafts of outgoing letters have been preserved for the period 1816-1827 (12 nos.); petitions and decisions thereon from 1805 ( 37 nos. with tables); Court Rolls and sentences from 1804 (10 nos.); instruments of evidence and oaths appertaining to sentences for 1806 (9 nos. with tables).

Draft pıoceedings of the Councillors Commissioned to hear pleas (Raden commissarissen tot het houden der dingtalen) begin as early as 1802 but continue only as far as 1817 (12 nos.); sentences of the said councillors have been preserved for the period 1804-1827, and appendices to the sentences for the period 1816-1827 (12 nos.).

Statements on revision of sentences, 1806-1825 (4 nos.) and case papers of civil and criminal cases, 1816-1827 (15 nos.) are also to be found in this group. Most of the volumes mentioned contain an index.

As regards the Councillor-Fiscal (Raad-fiscaal) the following documents have been preserved: government dispositions 1817-1827, incoming letters 1816-1824, police reports 1827-1828, and outgoing letters for the period 1816-1828 (42 nos.).

Personal data may be found in the ships' muster-rolls, 1821-1825 ( 4 nos. with index) and in a list of passengers arriving at Curaçao, 1819-1821.

The inventory of the Archives of the Commissioners for Minor questions and Disputes (Commissarissen van mindere questièn en geschillen) has also been published in the reporof the General State Archives for 1920, p. 652 et seq. (48 nos.). This court had been established in 1717 for cases involving sums not exceeding 300 pesos. It was known generally as the Little Council in contradistinction to the Grand Council of the Director and Councillors. It was only after a separate secretary had been appointed to the Little Council in 1756 that it began to form its own archives. 
The data for the first period are to be found in the series of resolutions and sentences of the Director and Councillors. Of the Little Council's papers those present are: court rolls with sentences and appendices 1757-1815 (41 nos., since 1771 with tables) and proceedings 18031815 (7 nos.).

The inventory relating to the $\mathrm{B}$ oard of $\mathrm{Commerce}$ and $\mathrm{M}$ a $\mathrm{r}$ ine A f a i rs (College van commercie en zeezaken) established by constitutional regulation of September 14, 1815, and charged with the administration of trade and maritime affairs, was published in the report of the General State Archives for 1920, p. 654, with a manuscript supplement inventory ( 22 nos.). There are also proceedings with appendices, since 1816 (11 nos.), court rolls with sentences 1816-1827 (12 nos.) and summonses issued by the Board with related documents 1822 1823 (1 no.).

In the reports for 1920 (p. 677-683) and 1924 (p. 136-137) the inventories of the archives of the Councillor-A c c oun tant-Ge n e$\mathrm{r}$ a 1 (Raad boekhouder-generaal) and the $\mathrm{C}$ o u $\mathrm{n} \mathrm{c}$ ill o r-C o m p t r o ller-General of finances, and other accountable o $\mathrm{f}$ i c e r s (Raad controleur-generaal van Financiën en andere comptabele ambtenaren) 1779-1828 have been published (184 nos., plus 4 more in a MS inventory).

The interim Directorate of the West-Indian Colonies had appointed a Councillor-Accountant-General on Curaçao in 1792. After the restoration of Dutch rule in 1816 this functionary was referred to as the Comptroller-General.

Only a few of the former councillor's documents have been preserved, viz., lists of accounts of government revenues, goods in stock, etc., 1792 (1 no.), a register of balance sheets 1795-1796 (1 no.), and incoming letters from Bonaire and Aruba 1799-1800 (1 no.).

The journals of day to day transactions of the office of the Councillor -Comptroller-General (Raad contrarolleur-generaal) have been preserved for the period 1816-1827 (10 nos.). Also incoming government circulars from 1819 (33 nos.); registers of outgoing letters (7 nos.) and General office ledgers (12 nos.), both series since 1816; taxation registers for the Collector-General from 1820 (3 nos.), idem for accountable officers from 1819 (6 nos.); registers of capitation and family-taxes, 1820, 1823 and 1827, listed topographically (10 nos.); idem for the store keeper, 1819-1821 (1 no.); several series of registration books 1816-1828 (34 nos.) among others concerning capitation and family tax, tunnage and import duties, pay rolls of civil servants $1816-1825$ (6 nos. partly with indices), transcript cash-books 1816-1825 (2 nos.), excise accounts 1816-1828 (1 no.), accounts of tonnages of foreign ships 1820-1821 (1 no.); a register of patent licences issued; a current account of the Commander of Bonaire and of the tax collector at Aruba, 1818-1821 (1 no.); a book of accounts from Aruba, 1821-1829 (1 no.).

Documents preserved relating to the office of the Collector-General (ontvanger-generaal), referred to after 1821 as the Collector-in-Chief, are: a consumption tax ledger 1818-1823 (with index), cash-books 1820-1822 (2 nos.), a register of taxes on houses and furniture 1828 
(1 no.), a journal of taxes received on horses, vehicles, ferries and tiltboats, and water-canoes 1820 ( 1 no.); a register of revenues for collateral inheritance 1816-1830 (1 no.), clearing journals 1818-1826 (5 nos.), a current account for import and export duties 1822-1827 (1 no.), a list of recognizances received for exported good 1823-1826 (1 no.); weighhouse records of incoming goods 1816-1826 ( 2 nos.), and a journal of legal fees received 1825-1826 (1 no.).

The Civil Servants' Pensions Fund (pensioenfonds voor ambtenaren, was founded in 1818. Proceedings of meetings of the administrative council with appendices are extant for the period 1819-1827 (9 nos.), as well as a journal, 1819-1827, and ledgers, 1819-1826 (2 nos.).

A separate functionary was installed in 1762 as auction master (vendumeester), from whose office auction books have been preserved from 1779 (18 nos.).

A separate office was set up for stamp duty receipts (ontvangst der zegelrechten), the journals of which are extant for the period 1809-1816 (5 nos.).

The papers of the military commander (militaive commandant) contain only incoming reports for 1805 (inventory in report of General State archives for 1924, p. 138; 1 no.).

The store-keeper (magazijnmeester) appointed in 1816, kept registers of goods received and distributed and of victuals; two of these are preserved covering the years 1822-1828, also a register of officers' rations for 1823-1828 (inventory in report for 1924, p. 138, and manuscript supplement, 2 nos.).

In the Civic Guard (schutterij) archives (inventory manuscript supplement, 4 nos.) we find the commander's incoming and outgoing papers, 1821-1824 (2 nos. with tables), a register of regulations and orders for the Citizen's Militia and the Civic Guard, 1816-1823 (1 no.) and a punishment book relating to non-commissioned officers, corporals and other ranks, 1823-1825 (1 no. with alphabetical index of names).

In 1828 a new constitutional regulation for the Netherlands Possessions was promulgated, which provided - as mentioned above - a central administration covering all the possessions in the West-Indies. The supreme authority in Curaçao, under the Governor-General, was vested in a Director, assisted by a Political Council. In 1833 the title of Director (directeur) was changed into that of Commander (gezaghebber) and the Political Council (Raad van Politie) was succeeded by a Colonial Council (Koloniale $\mathrm{Raad}$ ). The dependant islands were administered by a Commander subordinate to the Commander of Curaçao.

The office of the Governor-General established in 1828 was repealed in 1845 , so that from then on there was a direct relationship between the gezaghebber of Curaçao and dependencies and the 
Ministry of the Colonies. The gezaghebber's administration covered not only Curaçao, Aruba and Bonaire but also St. Eustatius, Saba and the Netherlands part on St. Martin. The new functionary assumed office on July 19, 1845.

The government archives for this period, 1828-1845, are listed in a manuscript inventory only.

The main series of the A r chives of $\mathrm{the}$ Director (directeur) or Commander (gezaghebber) and the Secretary of $\mathrm{t}$ h e C o l o n y (koloniale secretaris) (378 nos.) are the Director's journal for the said period, with appendices, 1819-1839 (30 nos.); incoming internal civilian letters ( 19 nos.) with 3 nos. of alphabetical repertories for the period 1824-1841; incoming military letters (18 nos.); letters from the naval authorities, 1827-1840 (14 nos.); idem from the Civic Guards and Reserve, 1828-1839 (12 nos. with repertory, 1 no.); letters from Bonaire and Aruba, 1828-1845 (18 nos., with 1 volume of repertory covering the period 1824-1842); incoming letters from abroad 1828-1829 (2 nos.) with repertory for the period 1834-1840 (1 no.). Further a general repertory of the incoming letters between 1827 and 1846 (6 nos.).

Although the letters received from the Netherlands are missing, a chronological repertory of them is extant for the period 1824-1836. Moreover, a series of petitions with appendices, 1828-1845 (21 nos.); requests for export permits for slaves, 1834-1846 (6 nos.); requests for the inhumation of corpses 1828-1847 (4 nos. partly with indices); for marriages without charge $1835-1840$ ( 1 no.). A repertory of the requests in general covers the period 1824-1833 only.

Also present are weekly reports from Dutch men of war, 1828-1834 ( 1 no.); the pilot's reports on incoming and outgoing ships 1828-1836 (1 no.), reports of the police commissioner on prisoners 1829-1836 (1 no.), reports from the Commander of the Engineers on the condition of government buildings 1825-1838 (1 no.), written reports from various officials on their inspection of imported victuals 1828-1840 (1 no. with table); rolls of the population of Curaçao compiled by wardmasters, 1838-1845 (1 no.).

The journals of the Commanders of Bonaire and Aruba are extant for the periods $1827-1837$ and 1827-1845 respectively (4 nos. and 12 nos.).

Government and Garrison Orders have been preserved for the period 1822-1834 (2 nos.), a register of letters to the mother country, 1826-1844 ( 1 no. with table); government circulars for the whole period (71 nos., with tables); registers of outgoing internal letters 1827-1845 (8 nos.) and letters to military authorities $1823-1839$ (3 nos.).

There is an alphabetical index to the military correspondence for the period 1834-1840 (1 no.).

Other outgoing papers contain letters concerning fortification, 18261833 ( 1 no.); letters to naval authorities $1827-1843$ (2 nos. with alphabetical index 1834-1840), letters to the commanders and other officials on Bonaire and Aruba 1816-1843 (5 nos.), outgoing letters to addresses abroad 1825-1840 (2 nos.), letters to captains of packet-ships 18271832 ( 1 no.), to trade commissioners, consuls and the representatives of various countries 1824-1843 (2 nos. with tables), letters to the store keeper 1827-1843 (1 no.; the index covering the period 1827-1841). 
Moreover, notifications from private persons concerning manumissions of slaves have been preserved, 1828-1832 (2 nos. with tables); instruments of oaths taken before the Director of the colony, 18321834 ( 3 nos.); a register of certificates issued between 1824 and 1836 (1 no.); letters of manumission with appendant documents, 1828-1836 ( 8 nos. with alphabetical index); instruments of security for obtaining letters of manumission, 1834-1839 (1 no.); a register (with notes) of letters received in the colony, 1832-1837 (1 no.), lists of persons arriving and departing, 1821-1842 (4 nos.); registers of passports issued, 18331844 ( 2 nos.); contracts for the hiring of government slaves by private persons, 1839-1840 (1 no.); a list of slave transfers, 1840-1842 (1 no.); regulations, instructions and notifications, 1794-1846 ( 6 nos., partly with index).

Manuscript and printed publications covering the whole period have been preserved in a series of 37 nos. with tables.

Among the documents concerning special subjects relative to either Curaçao, Bonaire and Aruba in general, or to one of these islands in particular, are an instruction issued to the supervisor of the gold mining on Aruba, circa 1827; papers concerning the administration of church and poor relief funds of the Protestant Church on Curaçao, 1826, and a register, with annotations, on the Indians of the so-called Wild Coast, who were living on Aruba in 1827; also financial documents concerning the islands; papers relating to civil servants; idem on the cultivation of cochineal imported from Cadix and on the import of sheep to improve the breed, 1837-1838; lists of foreigners present on the island, 1834-1836, a list of plantations (c. 1840), etc.

For Aruba a list of persons having lands under cultivation, with indication of the area cultivated in 1839 , has been preserved.

Among the papers dealt with by the secretary of the colony we may mention a register of outgoing letters, 1831-1840 (2 nos.), and an alphabetical repertory covering his correspondence, 1831-1840 (1 no., with alphabetical index).

The Political Council (Raad van Politie) was suspended when another constitutional regulation came into force. Its archives contain minutes and decisions with appendices, 1828-1834 (10 nos., with tables); incoming papers, 1828-1834 (6 nos., with tables); a register of outgoing letters, 1828-1833 (1 no.); sales contracts made before the Council, 1834 ( 1 no., with index); papers concerning appeals heard by the Council in 1832 ( 1 no.).

The archives contain draft proceedings of the Colonial Council (Koloniale Raad), which succeeded the Political Council in 1833 (12 nos.; tables for the period 1834-1835 only).

The Court of Civil and Criminal Justice (Raad van civiele en criminele Justitie) administered the law. This Court was replaced by the Bench for the Colony of Curaçao and Dependent Islands (Rechtbank der kolonie Curaçao en onderhorige eilanden) in accordance with the constitutional regulation of 1833. The Court's (later Bench's) archives contain minutes of meetings with appendices, 1828-1845 (18 nos., with tables); petitions received with the decisions thereupon, 1828-1845 (17 nos., with tables); 
registers of outgoing letters, 1828-1835 (1 no.); sentences of the Court (Bench), 1828-1845 (26 nos., with tables). The Bench recorded sentences in civil and in criminal cases separately. In addition, case papers concerning civil and criminal cases are present tor the period 1828-1845 (32 nos.). The Commissioned Councillors or Roll Commissioners (Raden Commissarissen of Commissarissen ter rolle) of the Court of Justice kept their own records, of which those for the period 1828-1845 still exist (17 nos.); also a register of sentences ( 3 nos. with tables); papers used by the Roll Commissioners, 1828-1845 (18 nos.); statements made and oaths taken, 1828-1844 (10 nos. with tables); deeds of appeal 1821-1832 (1 no.); a roll of appeals, 1831-1832 (1 no.); press notices regarding inheritances etc., 1828-1844 (6 nos., those for the period 1832-1836 with tables.)

The fiscal office had been suspended in 1828 . The police commissioner was charged with the function of public prosecutor and in 1834 he was replaced by a King's proctor. The archives contain all these officials' journals from 1829 to 1835 ( 9 nos.); also the documents received by the councillor-fiscal, later called the public prosecutor, 1828-1845 (36 nos., partly with tables); registers of outgoing letters, 1828-1845 (13 nos.); registers of remonstrances preferred by the public prosecutors, 18301835 (7 nos.); a register of judicial expenses 1822-1830 (1 no.); musterrolls of ship's crews, 1826-1844 (10 nos. mostly with alphabetical indices); transcript reports of the councillor-fiscal and his successors concerning prisoners, 1822-1836 (3 nos.); a current account kept between the Councillor-fiscal and the Police Commissioner on the one hand and the Collector on the other, 1822-1828 ( 1 no.); a register of funds received and deposited by the Clerk to the Court on behalf of the "Lazarus Fund", 1834-1839 (3 nos.); summonses of various judical courts, 1824-1829; testimonies of witnesses, 1833-1836, etc.

The Commission of $\mathrm{Puny} A \mathrm{ffairs}$ (College van kleine zaken), which administered justice in all cases involving amounts up to 150 guilders without practioners' assistance, functioned till 1833. In this year such affairs were brought under the jurisdiction of three members of the Bench, called Commissioners for Puny Affairs.

Their archives (45 nos.) contain draft proceedings with appendices (17 nos.); sentences ( 9 nos. with tables); documents used by the commissioners (16 nos.), lists of cases brought before them, 1829-1833 (2 nos.).

The $\mathrm{B}$ oard of $\mathrm{Commerce}$ and $\mathrm{Shipping} \mathrm{(College} \mathrm{voor}$ commercie en zeevaart) adjudicated all cases which in the Netherlands were referred to the Commercial Courts. In cases involving more than 300 guilders appeals were heard by the Political Council. In 1834 the Board of Commerce and Shipping was abolished and the cases it had dealt with were henceforth decided by the Colonial Council. The archives contain 15 numbers in all, 6 comprising minutes with appendices, 2, registers of sentences from 1828 to 1833 , with tables, and 7, papers used by the Board.

In 1828 the administration of financial affairs (verschillende financiēle ambtenaren) was put in the hands of a Comptroller, his title being altered in 1833 to that of Administrator. The archives 
(158 nos.), which are divided into five sections, viz., those of the Comptroller (Administrator), of the Collector, the Comptroller's subordinated, of the administration of the Civil Servant's Pensions Fund of the Auctioneer and the pilotage records contain the following documents:

Comptroller (controleur or administrateur)'s documents: journals of official business, 1828-37, 1839 (10 nos.); registers of outgoing letters (13 nos.); receipts and expenditures cash book, 1828-1833 (1 no.); bookkeeper-auditor's journal of receipts and expenditures, 1830-1831 (1 no.); general office ledgers (18 nos.); registers containing statements of receipts and expenditures, 1833-1845, (8 nos.); idem regarding orders to pay (10 nos.); idem regarding property tax paid, 1831-1844 (6 nos.); registers of assessments of property tax, 1827-1844 (21 nos.); list of creditors, 1828-1840 (2 nos.); invoice books, 1836-1845 (2 nos.); register of expenditure according to the budget, 1834-1851 (3 nos.), one of these numbers (1834-1837) contains lists covering the period 1823-1830 of deceased persons, grouped according to religious denomination, in connection with their estates; lists of salaries, pensions and gratuities paid out to civil servants, 1826-1845 (9 nos.); reserve cash books, 1826-1841 (2 nos.); cash accounts, 1837-1844 (1 no.); contracts regarding various deliveries, 1825-1834 (2 nos.); budget statements for Curaçao and dependent islands for the period 1828-1836 and 1844, with relevant papers ( 1 no. with table); lists of daily wages, accounts for materials, etc., for the maintenance of Government buildings, 18271836, 1844 (1 no.); monthly statements of finances and of accounts chargeable to the Government, 1835 (1 no.); register of the value of imported or confiscated goods, 1828 (1 no.).

The records of the Collector (ontvanger) comprise: tax registers, 1827-1842 (4 nos.); Chief Collector's registration books, 1828-1845, (13 nos. partly with tables of contents); papers concerning collection of taxes by legal action, 1828-1832 (1 no.).

The records of the Civil Servants Pensions Fund (pensioenfonds van ambtenaren) contain: minutes of the meetings of the Board of Administration, with appendices, 1828-1845 (11 nos.); incoming documents, 1843-1845 (1 no.); register of outgoing letters to the Head Administrative Office for Pensions at the Hague and to officials on Curaçao and dependent islands, 1819-1838 (1 no.); Pensions Fund Ledger, 18271834 (1 no.).

The auction master (vendumeester)'s records contain the auction books, 1827-1844 (11 nos.) with alphabetical indices. The Pilotage (loodswezen) records contain a pilot's receipts and expenditures cash book, 1828-1838 (1 no.).

Some financial documents are to be found in the records of the military commander (militaire commandant; 3 nos.). These include statements of food supplies received and used in the military hospital, 1837 (1 no.); statement of artillery material received and issued for the forts, 1831, 1836-1837; pay lists of men employed by the artillery in Curaçao, 1829 (1 no.).

In the storekeeper's records (magazijnmeester; 5 nos.) a tax register is to be found, 1821-1830 (2 nos.); also invoices for foodstuffs, etc., 
received in Curaçao from the Netherlands, 1816-1828; invoices for military and other goods delivered from Surinam, with appendices, 1830-1837 (1 no.); statement of goods in stock and goods issued from the garrison's clothing store, 1837-1838 (1 no.).

The records of the Civic Guard (schutterij) and the Reserve (landstorm; 40 nos.) divided into two sections, viz., those of the Commander of the Civic Guard and those of the Commander of the Reserve, contain, in the first section, documents received by the Commander, 1825-1845 (5 nos.), with tables; regist $\mathrm{r}$ of the Commander's outgoing letters, 1825 1836 (1 no.) with table; battalion orders, 1821-1845 (7 nos.) partly with tables of contents; statements of the strength of the Civic Guard and Reserve, 1821-1845 (4 nos.); punishment roll for non-commissioned officers and corporals of the Civic Guard, 1835-1838 (1 no.); guard duty rosters of the Civic Guard, 1835-1845 (11 nos.); register of fines collected from officers, non-commissioned officers and other ranks of the Civic Guard, 1821-1830 ( 1 no.); statement of the clothing and weapons of the Civic Guard and Reserve, 1837-1838 (1 no.). The records of the Commander of the Reserve include papers received by the Commander from the Governor (Director) of Curaçao, 1822-1845 (1 no.); other documents received, 1827-1838 (3 nos.); outgoing orders and letters from the Commander, 1825-1838 (2 nos.); statements of the strength of the Reserve, 1839-1841 (3 nos.).

By the Constitutional Regulation of 1828 the administration of local affairs had been put in the hands of a Municipal Council. In 1832 the administrative system of Curaçao was simplified, the activities of the municipal administration being transferred to the Political Council.

The archives of the municipal administration (gemeentebestuur 42 nos.) including the old ecclesiastical and civil registration (Burgerlijke stand) records had to be transferred to the Government Secretariat, while the financial administration now came under the bookkeeper-auditor.

As regards the municipal administration the following documents have been preserved: draft proceedings of meetings, 1829-1833 (5 nos.); government notifications received, 1828 and 1831 (2 nos.); papers received from the Colonial Director, 1829-1833 (5 nos.); reports, etc., received from various bodies and officials, 1828-1832 (4 nos.); reports from the Orphans' Trustees submitted to the municipal government, 1832-1833 (1 no.); petitions received, 1828 (1 no.) with table; repertory appertaining to incoming documents, 1828-1832 (1 no.); register of the outgoing letters of the Chairman of the Municipal Council, 1828-1833 ( 2 nos.); alphabetical repertory of the latter's correspondence, 18281832 ( 1 no.); official reports of cash verifications and audit of the administration of accountable institutes and officials, 1828-1833 (3 nos.); accounts of receipts and expenditures of the Protestant Church and of the Orphans', Ownerless and Insolvent Estate Court for the years 1828-1829, with appendices (1 no.); accounts of receipts and expenditures of church and other organizations, 1829-1832 (2 nos.); budget estimates and accounts of receipts and expenditures of the municipal administration, 1829-1832 ( 1 no.); papers concerning the municipal 
budget for the years 1829-1832 (1 no.); notifications received by officials of the Civil Registration Office, 1831-1832 (1 no.); notifications from various authorities received by the secretary and collector of the municipal administration, 1831-1832 (1 no.); memorandum books of the municipal collector, 1830-1833 (2 nos.); journals of the Police Commissioner, 1827-1834 (8 nos.).

The inventory of the Orphans' and Estate Court (Weesen Boedelkamer) 1709-1845 (1876), has been published as far as the year 1828 in the State Archives Report, 1920, p. 673-677 (78 nos.). For the period 1828-1876 a manuscript inventory only exists (101 nos.).

No archival remains exist covering the administration carried on by the Orphans' Trustees during the 17 th century. The oldest ledger preserved commences in 1709 .

In the 18th century the administration of the Orphans' Court was put in the hands of two Orphans' Trustees, who also had to take charge of ownerless estate. In accordance with the Constitutional Regulation of 1815 an Orphans' Ownerless and Insolvent Estate office was set up on Curaçao. In 1870 this Office was abolished once the estates concerned had been dealt with. A separate administration was set up for the management of the private funds and the guarantee capital, now separate from the Orphans' Court. The management of these funds fell to the Mortgage Bank of Curaçao. In 1876 the Orphans' Court and the Mortgage Bank were both dissolved in their entirety, while the funds not received before Nov. 1. 1876 were booked in the administration to the names of the parties entitled or to the names to which they had been booked by the Mortgage Bank of Curaçao, founded in 1875; meanwhile the records were deposited with the Government Secretariat.

The relevant archives contain: proceedings of the Board of the Orphans' Court, with appendices, 1817-1870 (50 numbers), of which those subsequent to 1828 are in badly damaged condition; registers of outgoing letters from the Orphans' Trustees or from the secretary of the Orphans' and Ownerless Estate Court, 1771-1870 (10 nos.), damaged after 1817; journals, 1710-1876 (16 nos.); ledgers, 1709-1876 (17 nos.) with alphabetical name-tabs; cash books 1777-1874 (20 nos.); cash account books, 1770-1840 (8 nos.); memoranda regarding estate, 17731845 (7 nos.), with alphabetical name-tabs as from 1777; estate accounts books, 1769-1869 (7 nos., as from 1777 with alphabetical name-tabs); estate accounts with appendices, 1787-1869 (45 nos.); accounts book regarding management of houses, 1774-1783 (1 no.); monthly lists of receipts and expenditures, 1833-1845 (1 no.); statement and accounts book of administered capital due to creditors, 1821-1845 (1 no.); a statement of account based on the ledger for the years 1857-1869 (1 no.); alphabetical lists of names regarding payments of interest on outstanding capital, 1858-1875 (1 no.); lists of unidentified estates, referred to the Orphans' Court, 1850-1869 (1 no.); lists of donations received in aid of the hospital and mental asylum, with notes regarding patients, 18311838 ( 1 no.); list of resolutions of the Political Council, in 1833 still in force since 1828 (1 no.).

An inventory of the Secretarial and Notarial Protocols (Secretariële en notariële protocollen), 1708-1845, exists up to 
1828, printed in the 1920 Report, p. 655-673 and the 1924 Report, p. 135 (458 nos.). An MS inventory only exists for the period after 1828(126 nos.).

These protocols represent a group of public deeds executed by two councillors, the Director (Governor), or an official functioning as a notary. The first kind are referred to as secretarial deeds, the second as notarial deeds. Secretarial deeds executed by Councillors were deeds of conveyance and mortage regarding real estate, and marriage banns and licences. The deeds were prepared by the Clerk to the Director and Council.

In 1816 the Political Council became responsible for attesting the execution of mortgage deeds and deeds of conveyance regarding real estate. The secretaries were authorized to draw up notarial deeds, though a sworn clerk of the secretariat could deputize for them. The tables of the secretaries' protocols are arranged according to the different sorts of deeds in alphabetic order. Secretarial and notarial protocols have been preserved as from 1708. In the early years only fragments remain, but the series is consecutive after 1730 and is supplied with tables as from 1780 , the tables for that year, however, being incomplete.

The mortgage deeds form a separate series starting in 1721, with tables from 1770

Of the old records of the Registrar's Office (Retroacta van de Burgerlijke Stand), an Inventory (34 nos.) has been published in the 1920 Report, p. 684-685.

They include: deeds relating to notices of intended marriage, 18071816 (8 nos.), with tables; baptismal registers of the Dutch Reformed Church, 1727-1820 (5 nos.); the banns and marriage registers of the aforementioned Church, 1714-1822 (7 nos.); a baptismal register of the Lutheran Church, 1757-1825 (1 no.); baptismal registers of the Roman Catholic Church, 1768-1819 (9 nos.). All the above books show fairly considerable gaps. Also present are: lists of births among Portuguese Jews with notes of their decease, 1722-1831 (1 no.) and a journal of receipt of church burial dues, etc., 1769-1831 (3 nos.) with alphabetical name-tabs.

An MS inventory of the records of the Mortgage Bank of Curaçao (hypotheekbank van Curaf̧a), mentioned above in connection with the Orphans' and Estate Court, is present (22 nos.).

In 1875 the management of this bank was taken over by the Curaçao Mortgage Bank Ltd., which was founded in the same year. The inventory contains minutes of meetings of the Board of Directors, with appendices, 1870-1875 (6 nos.); registers of outgoing letters 1870-1876 (2 nos., very badly damaged), letters received by the Liquidator of the Mortgage Bank of Curaçao, 1876 (1 no.); journals, 1871-1876 (4 nos.); cash books, 1870-1876 (4 nos.); balance-account, 1870-1875 (1 no.); register of mortgage sums of the Orphans' and Estate Court and, from 1871, of the Mortgage Bank of Curaçao, 1863-1875 (1 no.); expenses book of the Orphans' Court Administration, subsequently of the Mortgage Bank of Curaçao, 1859-1876 (1 no.); certificates of discharge in favour of the administrators of the liquidated Mortgage Bank of Curaçao in respect of 
claims taken over by the new Curaçao Mortgage Bank Ltd., 1876 (1 no.) records of the transfer of moneys, documents and goods by the Board of the liquidated Mortgage Bank of Curaçao to the Curaçao Mortgage Bank Ltd., 1876-1877 (1 no.).

The islands of BONAIRE and ARUBa were subordinate to the Director of Curaçao; the archives, however, were kept separately from 1816 onward, those relating to these islands prior to this date being included in the Curaçao archives.

Of the Bonaire archives, an inventory of which, 1816-1828, has been published in the 1920 Report, p. 685 (2 nos.) plus a supplementary inventory (1 no.), only the journals of the Commander, 1816-1826, 1827-1828, and of the Deputy Commander, 1828, have been preserved (3 nos.).

The archives of the Commander of Bonaire, 1827-1845, have a MS inventory (22 nos.). They include: the journals, 1829-1843 (8 nos.); decisions received from the Director (later Commander) of Curaçao and dependent islands, 1830-1845 (7 nos.); letters received 1837-1838 (1 no.); and registers of outgoing letters from the Commander, $1827-1845$ (6 nos.).

The inventory of the $a r c h i v e s$ of $A r u b a$ 1816-1845 (23 nos.) has been published in the Report for 1920, p. 685-687, and in MS form (61 nos.).

Documents present are: the Commander's journals, 1821-1848 (11 nos.); government notifications received by the Commander, 18161826 (3 nos.) with tables; papers received by the Commander from the Director (later Commander) at Curaçao, 1830-1845 (7 nos.) with tables; missives and papers received by the Commander, 1818-1839 (4 nos.); register of the Commander's outgoing letters, 1818-1848 (6 nos.); proceedings of the Magistrate's (Justice of the Peace) Court, 1824-1827, 1838-1844 (2 nos.); protocols of secretarial deeds (deeds of conveyance for real estate) 1816-1848 (8 nos.) with tables; idem for notarial deeds, 1816-1845 (20 nos.) with tables; mortgage deeds, 1816-1847 (6 nos.) with tables; journal of receipts and expenditures, 1842-1844 (1 no.); registration book regarding financial affairs maintained at the colonial bureau, 1843-1846 (1 no.); "De Curaçaosche Courant" (The Curaçao News), 1818-1846 (15 nos.).

The archives of the islands of St. Eustatius, St. Martin and SABA were also transferred to the Netherlands by the Royal Decrees of Dec. 22, 1915, .July 7, 1919 and May 12, 1930. Up to 1828 the governments of S Martin and Saba were subordinate to that of St. Eustatius except for the period 1802-1816. In 1802 the constitutional bond uniting St. Eustatius with the other two islands was severed, the government of Saba being subordinate to that of St. Martin from 1802 until 1816. A large part of the archives has been lost. 
Of the $S t$. Eust atius archives only those subsequent to 1781 have been preserved. On occupyirg the island in that year, the English destroyed the government archives, the ecclesiastical archives only having been saved. After takirg $\mathbf{S}$ :. Martin in 1810, the English likewise destroyed a part of the secretariat papers, while more papers were lost in a hurricane in 1819. The ancient ecclesiastical registers are also missing from the old Civil Registration archives. They were deposited with members of the clergy and were lost during a hurricane in 1792. On both St. Martin and Saba authority resided in a vice-commander responsible to the government on St. Eustatius.

As regards the government archives of St. Eustatius the inventory of the a rchives of $\mathrm{the}$ Governor (Gouverneur; after 1795 the Captain-Commander and in 1801 the Commander) and $\mathrm{C}$ o u n c i llors (Raden), 1781-1802, has been published in the Report for 1924, p. 99-103 (35 nos.)(with a MS supplement (1 no.).

The papers preserved are: proceedings of the meetings of the Governor (Captain-Commander, Commander) and Councillors, 1785-1787, 17901802 (10 nos.); petitions received and the decisions thereupon, 1782-1802 (13 nos.); documents received, 1783-1796 (1 no.); register of notifications, 1785-1802 (3 nos.); civil court rolls, 1790-1792 (1 no.); civil sentences, 1790-1797 (1 no.); fiscal roll, 1792-1793 (1 no.); judicial documents, 1786-1794 (2 noc) ; registor of summonses, 1782-1791 ( $\angle$ nos.); register of verdicts, $1785-1792$ (1 no.).

The inventory of the a rchives of the Governor, Political Council and the Court of Justice 1802-1828 (1835) has been published in the Report for 1924, p. 103-108 (86 nos.), with a MS supplementary inventory (5 nos.).

The governor (gouverneur)'s archives include letters received from the Colonial Office, 1815-1828 (9 nos.); letters received from the authorities on St. Eustatius, 1816-1828 (1835) (1 no.); petitions received with the decisions thereupon, 1817-1828 (2 nos.); letters received from the military authorities, $1828-1832$ (1 no.); letters received from the accountant-general, 1818-1828 (1 no.); letters received from St. Martin, 1816-1828 (1835) (3 nos.); journals of the Commander of St. Martin and Saba, after 1821 of the President of the Political Council of St. Martin, 1821-1826 (2 nos.); proceedings of the Political Council of St. Martin, 1817-1826 (1 no.); letters received from the Juridical Council of St. Martin, 1821-1827 (1 no.); the proceedings of this Council, 1824-1826 (1 no.); documents received from St. Martin, 1816-1827 (1 no.); letters received from the Vice-Commander of Saba, 1816-1828 (1835) (1 no.); letters received from the Governor General (Governor) of Curaçao, 1818-1828 (1835) (1 no.); letters received from the Governor of Surinam, 1822-1826 (1 no.); letters from authorities in other countries, 1817-1828 (1834) (1 no.); register of outgoing letters addressed to the Colonial Office, 1815-1828 (3 nos.); register of outgoing advice notes relating to bills of exchange despatched to the Colonial Office, 1817-1828 (1 no.); idem to 
various authorities in the West Indian Colonies etc., 1824-1828 (3 nos.); register of letters despatched to military authorities, 1818-1825 (1 no.); idem to the accountant-general, 1817-1821 (1 no.); idem to St. Martin, 1817-1828 (1 no.); regulations and instructions, 1817-1826 (2 nos.).

The archives of the Political Council (Raadvan Politie) and the Juridical Council (Raad van Justitie) contain proceedings of the meetings of the Governor (Commander) and Councillors of the Political Council, 1802-1829 (1832) (3 nos.); decisions on petitions, 1803-1816 (1 no.); petitions received by the Political Council and the Juridical Council with connected documents, 1803-1829 (1832) (4 nos.); registers of notifications, 1802-1817 (2 nos.); proceedings of the Juridical Council, 1802-1803 (1 no.); civil court roll, 1803-1816 (1 no.); fiscal roll, 18031816 (1 no.); Juridical Council proceedings with court rolls, 1816-1829 (14 nos.); letters received by the Juridical Council, 1818-1829 (1833) (1 no.); register of summonses 1803-1829 (1831) (14 nos.); register of summonses and remains, 1803-1829 (1832) (4 nos.); register of verdicts, 1803-1829 (3 nos.).

Therecords of the Accountant-General and other a c c o untable officers 1792-1828 (1851) are published in the 1924 Report, p. 112-114 (30 nos.).

These contain the accountant-general (boekhouder-generaal)'s ledgers 1818-1828 (6 nos.); general tax registers, 1818-1828 (3 nos.); register of receipts issued, 1828-1831 (1 no.); register of orders to pay, 18181826 (1 no.); reserve cash books, 1816-1828 (2 nos.).

The only document of the Collector-General (ontvanger-generaal) present in these archives is a cash book, 1819-1830 (1 no.).

Papers of the Civil Servants' Pensions Fund's Administrative Council (Raad van administratie van het pensioenfonds voor ambtenaren) preserved contain: proceedings of the meetings, 1819-1848 (1 no.); letters received from the Colonial Office, etc., 1820-1829 (1 no.), with table; letters received, 1822-1833 (1 no.) with table; register of outgoing papers, 1819-1841 (2 nos.); ledger, 1819-1851 (1 no.).

Auction Master (vendu-meester)'s papers present are: journals, 17941828 (8 nos.). Besides this, another journal, of the collector of import and export duties (ontvanger der inkomende en uitgaande rechten), has been preserved covering the period 1792-1797 (1 no.).

Among the deposited papers (gedeponeerde stukken) must be reckoned printed documents regarding military affairs and issued from the War Office, 1815-1817 (4 nos.); a book of minutes belonging to the English Church on St. Eustatius, 1752-1790 (1 no.); and papers originating from the firm of Anthony Beaujon and Sons on St. Eustatius, 1780-1787 (1 no.)

In 1828, by decision of the Commissioner-General for the WestIndian Possessions, a Commander of St. Eustatius and Saba was appointed, subordinate to the Governor-General, to replace the former Governor of St. Eustatius, St. Martin and Saba. St. Martin was no longer a dependency of St. Eustatius but subordinate only to the General Government of the West Indies. The admini- 
stration of local affairs was entrusted to a Municipal Council. In 1833 the Commander of St. Eustatius was assisted by a Colonial Council which replaced the Municipal Council. The Commander of St. Eustatius exercised authority over the dependent island of Saba via the intermediary of a Vice Commander.

Only MS inventories are present covering the government a r c h ive s for the period 1828-1845.

The archives of the Commander, 1828-1845 (1846) (27 nos.) contain journals of the Commander (Commandeur), after 1833, of the Gezaghebber, 1828-1839 (4 nos.); the journal of the Vice-President of the Political Council, ad interim Commander, 1828 (1 no.); documents received from the Governor-General, 1828-1845 (10 nos.); documents received from the Military Office of the Governor-General, 1828-1836 (2 nos.); documents received from various bodies and authorities, 1828-1835 (1 no.); financial documents received from the bookkeeper, storekeeper and other functionaries, 1828-1833 (1 no.); papers received from private individuals, $1828-1835$ (1 no.); list of documents received 1836-1838 (1 no.); repertory of outgoing documents 1836-1841 (2 nos.); register of publications, notifications, $1828-1835$ ( 1 no.); letters of manumission 1836-1846, (1 no.); notices regarding slaves issued by the secretary of the colony, 1843-1846 (1 no.).

No documents of the Municipal Council (gemeenteraad), known after 1833 as the Colonial Council (koloniale raad), have been transferred to the Netherlands.

Papers belonging to the archives of the Court of Civil and Criminal Justice (Raad van civiele en criminele Justitie), known subsequent to 1834 as the Bench (rechtbank; 3 nos.) contain: documents received, 1828-1834 (1 no.); register of verdicts, 1830 (1 no.); case papers, 1833 1845 (1 no.).

All civil cases involving not more than 150 guilders were decided by the Commission (from 1833 on, the Commissioners) for Puny Affairs (College, from 1833 commissarissen, tot de Kleine Zaken. The proceedings of the meetings of the commission are present for the period 1829-1831 (1 no.).

The records of the Accountant-General (boekhouder-generaal) (from 1833 on, the Financial Administrator (administrateur der Financienn), also those of the Colonial Collector and other accountable officials (koloniale ontvanger en andere comptabele ambtenaren), 1828-1845 (1852) (24 nos.), include a register of outgoing letters, 1828-1852 (1 no.); a general ledger, 1829-1839 (4 nos.), partly with indices; the Collector's General Office cash book, 1834 (1 no.); receipted orders to pay, 18281845 (18 nos.).

The records of the Storekeeper (magazijnmeester) 1829 (2 nos.) contain a General Store stock book, 1829. 
The Constitutional Regulation of 1815 set up an Orphans' and Ownerless Estate Court (Wees- en onbeheerde boedelkamer) for St. Eustatius (inventory in the 1924 Report, p. 112, 5 nos.), which Court continued unchanged by the Constitutional Regulation of 1828 . No papers relating to this later period have been tranferred to the Netherlands. The documents present are: proceedings of the Court, 1816-1832, with appendices 1816-1828 (4 nos.); register of estate accounts, 1819-1832 (1 no.).

The inventory of the secretarial and notarial protocols (scabinale of secretarièle protocollen), 1781-1829 (1869) has been published in the 1924 Report, p. 109-111 (84 nos.) with a supplementary MS inventory (1 no.). Only one volume of estate inventories, 1829-1834, has been transferred to the Netherlands for the period subsequent to 1828 .

The secretarial protocols contain the deeds attested by the Governor. These include instruments of conveyance and mortgage, ships' charters and musterrolls. Notarial deeds were executed in the presence of the secretary. Most of these protocols are supplied with tables.

The inventory of the old ecclesiastical and civil registration records (retroacta van de Burgerlijke Stand) 1710-1817 has been published in the 1924 Report, p. 114 (14 nos.). It contains registers of (civil) marriage banns, applications and weddings, 1787-1816 (4 nos.); idem for Jews, 1786-1796 (1 no.); register of deaths, 1793-1817 (1 no.); baptismal register of the Dutch Reformed Church, 1709-1791 (4 nos.); registers of banns and marriages of the Dutch Reformed Church, 1710-1791 (4 nos.).

During the 18th century the Vice-Commandership of SABA was subordinate to the government established on St. Eustatius After having been captured by the English, the island was returned to the Netherlands in 1803 . There were then a Vice-Commander and Councillors on Saba who continued in office on the orders of the Governor of St. Martin and Saba. The title of ViceCommander was changed to that of Vice-Governor. In 1810 the island was taken by the English once again. Dutch authority was re-established there in 1816. The Vice-Governor continued in office as the Vice-Commander, subordinate to the Commander of St. Martin and Saba. Appointments were made to the Political and Juridical Council.

Appeals on sentences passed by this Council could be made to the Juridical Council on St. Martin. In 1820 a change was made in the constitutional relationship existing between Saba and the command on St. Martin, whereby the Vice-Command on Saba came directly under the supreme authority of the Governor of St. Eustatius, St. Martin and Saba. The Government Settlement of 1828 left Saba linked constitutionally to St. Eustatius.

The inventory of the $S a b a$ archives 1780-1828 (1868) has been published in the 1924 Report, p. 131-132 (5 nos.). It contains letters 
from St. Eustatius and St. Martin received by the Vice-Commander, 1818-1829 (1 no.); proceedings of the Political and Juridical Council, 1812-1828 (1868) (1 no.); register of deeds recorded by the secretary, 1825-1828 (1840) (1 no.); auction books, 1780-1828 (1855) (2 nos.).

After the conquest by the Commander of St. Eustatius of a part of ST. MARTIN in 1703 the government of the island was organized. The Commander of St. Eustatius appointed a ViceCommander on the island, which Vice-Commander was assisted in the task of administration by a Council chosen from among the island's inhabitants.

In 1719 a French Commander was permitted to enter the island and took over the administration of the former French zone of the island. The governor on St. Martin was referred to as the ViceCommander on St. Eustatius, but on St. Martin itself he took the title of Commander.

In 1781 the island was captured by the English who evacuated it once again during the same year. The French, who held it on behalf of the States General, retained the former Commander as Governor, and in 1784 they returned the island to the Dutch. In 1785 a new Vice-Commander was appointed whose title was changed once again in 1786 to that of Commander.

In 1795 the Commander of St. Martin signed an agreement with the French Commissioners on Guadeloupe whereby the military command of the island was, among other things, to be transferred to the French. The Commander and his Councillors continued to exercise civil authority. In 1801 the island was conquered by the British who handed over the administration of the Dutch part of the island to the Dutch Government in 1802.

Of the St. Martin archives for the period 1729-1802 only those of the Commander and Councillors (commandeur en Raden) from 1729-1802 have been preserved, the inventory of which has been published in the 1924 Report, p. 115-120 (58 nos.) with a supplementary MS (9 nos.). These archives contain the proceedings (draft and copy) of the meetings and the court rolls of the Commander (Governor) and Councillors, 1729-1801 (14 nos.); petition rolls, 1793-1801 (2 nos.); petitions received with decisions thereupon, 1735-1800 (2 nos.); papers received from the West India Company, 1751-1799 (2 nos.); idem from St. Eustatius, 1737-1798 (1 no.); idem from the French zone of St. Martin, 1785-1797 (4 nos.); land survey reports received by the Commander, 1738-1786 (1 no.); registers of letters to the West India Company, 1778-1791 (1 no.); registers of letters to St. Eustatius and St. Martin, 1742-1798 (6 nos.); papers concerning relations between the Dutch and the French zones, 1734-1799 (3 nos.); copies of instructions, $1778-1779$ (1 no.); edicts, publications and notifi- 
cations, 1733-1801 (6 nos.); various inventories of documents concerning St. Martin, 1770-1801 (5 nos.); ordinary and extraordinary court rolls, 1790-1801 (4 nos.); fiscal roll, 1790-1800 (1 no.); cases papers, civil and criminal, 1717-1801 (5 nos.); register of summonses and verdicts etc., $1755-1799$ (5 nos.).

When Dutch authority was re-established over the island of St. Martin in 1802 the former constitutional relationship existing between the island and St. Eustatius was brought to an end, while Saba was made a dependency of St. Martin. In addition to the Governor a Political Council was appointed which was refurred to as the Juridical Council when it dealt with juridical matters In 1810 the islands went over to the English and supreme authority was then vested in a civil and military commander, who functioned as acting Governor and administered the island with the assistance of the Councillors. The Dutch administration was restored in 1816, and a Constitutional Regulation came into force covering St. Eustatius, St. Martin and Saba, whereby the Commander of St. Martin and Saba was made subject to the orders of the Governor of St. Eustatius. The Political Council and the Juridical Council of St. Martin dealt with the affairs of Saba also.

In 1820 the administration of St. Martin was again simplified The island of Saba now came directly under the authority of St. Eustatius. The government of St. Martin was headed by the President of the Political Council on that island, acting under the authority of the Governor of St. Eustatius.

The constitutional link uniting St. Martin with St. Eustatius was severed in 1828 , the government of the former being no long $r$ subordinate to that of St. Eustatius but to the General Government seated in Surinam. For the rest, the existing government structure on St. Martin continued in being.

The inventory of the a $\mathrm{rch}$ ives of $\mathrm{the}$ Governor ( $\mathrm{Com}$. mander) of St. Martin and Saba, the Political Council and Juridical Council, 1802-1816, of the Commander of St. Martin and Saba, the Political Council and Juridical Council, 1816-1821, of the President of the Political Council and Juridical Council 1821-1828, has been published in the 1924 Report, p. 120-125 (78 nos.), with a MS inventory ( 35 nos.).

The archives of the Governor (Commander) and President of the Political Council contain papers concerning the Governor's acceptance of office in 1802 ( 1 no.); papers relating to the organization of the government on Saba, 1803 (1 no.); publications of the Civil and Military Commander, 1815-1816 (1 no.); papers relating to the transfer of St. 
Martin to Dutch rule and the organization of the government on Saba, 1816 (1 no.); journals of the Commander of St. Martin and Saba and, after 1821, those of the President of the Political Council of St. Martin, 1817-1827 (6 nos.); instructions, 1816 (1 no.); letters from the Colonial Office, 1814-1828 (2 nos.); letters from St. Eustatius, 1816-1828 (2 nos.); incoming letters, reports, petitions, etc., from officials and private individuals on St. Martin and elsewhere, 1816-1827 (12 nos.); papers from Saba, 1817-1818 (1 no.); letters from the government of the French zone of St. Martin and from the governments of other foreign islands (St. Bartholomew, St. Thomas, etc., 1816-1827 (1 no.); outgoing letters to the Colonial Office, 1817, 1826 (2 nos.); idem to the Governor of St. Eustatius, St. Martin and Saba, 1820 (1 no.); idem to various authorities, bodies and others, 1820 ( 1 no.); idem to the Garrison Commander, 1820-1823 (1 no.); rolls of persons in the Dutch and French zones of St. Martin who swore the oath of allegiance to the English government, 1811-1813 (1 no.); register of oaths of allegiance sworn by inhabitants of St. Martin to the King of the Netherlands ,1816-1828 (1 no.); register of (land) title deeds issued, 1806-1807 (1 no.); register with extracts from the regimental roll of officers of the Rifles Battalion detached to the islands of St. Martin and St. Eustatius, 1827 (1 no.) damaged; miscellaneous papers including, interalia, statements relating to deceased soldiers, 1819; draft report on St. Martin and Saba, 1818, 1819; lists of departing passengers, 1826 (1 no.).

The archives of the Political Council (Raad van Politie) and the Juridical Council (Raad van Justitie) include a register of resolutions passed by the Commander and the Political Councillors, 1819 (1 no.); proceedings of the Political Council, 1802-1828 (1831) (7 nos.); petitions received by the Political Council and the decisions taken thereon, 18021824 (7 nos.); minutes addressed to the Governor and Commander by the Political and Juridical Councils, 1804-1815 (2 nos.); registers of publications and notifications issued by the Governor and Councillors, 1802-1809 (2 nos.); register of publications by the Political Council and Juridical Council, 1816-1828 (1831) (2 nos.); minutes of the meetings of the Juridical Council, 1803-1825 (5 nos.); petitions received by Juridical Council and decisions thereupon, 1802-1828/1829 (4 nos.); ordinary and extraordinary court rolls, 1803-1823 (15 nos.); fiscal rolls, 18031823 (13 nos.); puny affairs court roll, 1803-1805 (1 no.); case papers, civil and criminal, 1803-1812 (1 no.); appendices to the court rolls, 1817-1823 (3 nos.); registers of summonses, 1804-1828 (3 nos.); register of notifications, 1802-1828; idem of verdicts, proclamations, protests, appeals, 1802-1824 (4 nos.).

The inventory of the archives of the Commissioners for Puny Affairs (Commissarissen tot de Kleine Zaken), 1790-1794 has been published in the 1924 Report, p. 126 (3 nos.) and includes court rolls, 1790-1794 (2 nos.) and a register of summonses, 1790-1794 (1 no.).

The inventory of the archives of the bookkeeper and other accountable officials (boekhouder en andere comptable ambtenaren), 1739-1828 (1831) has been published in the 1924 Report, p. 129-130 with a supplement- 
ary MS (6 nos.) and contains the bookkeeper's ledgers, 1816-1826 (6 nos., partly with indices); the auction master's documents include: lists of auction notices, 1786-1797 (1 no.); auction books, 1739-1828 (17 nos.); seller-creditor ledger, $1785-1796$ (1 no.); purchaser-debtor ledger, 1768-1791 (2 nos.); lists of receipts, 1779-1801 (4 nos.); receipt books, 1742-1811 (4 nos.); statement of public sale of real estate, 17851809 (1 no.).

The archives contain the following documents of the Collector of incoming and outgoing duties: lists of ships arriving and departing, 1804-1805 (1 no.); monthly returns supplied by planters and merchants of the quantity of sugar and rum in their charge, 1811-1815 (1 no.).

The storekeeper's records (archief van de magazijnmeester), 1817, MS inventory (1 no.) include: statements of goods in the general store under the storekeeper's control, 1817 (1 no.).

The deposited papers (gedeponeerde stukken), 1726-1820, inventory in the 1924 Report, p. 130-131 (6 nos.), with MS Supplement (1 no.) include: copy of the proceedings of meetings of the Church Council of the Dutch Reformed Church on St. Martin, 1791-1792 (1 no.); a members subscription list of the English Church on St. Martin regarding the collection of funds for the repair of the church, undated (1 no.); property deeds relating to the plantations of St. Andrews' Hill, Bishopshill and Belvedere, 1726-1797 (1 no.); papers relating to the Golden Rock sugar plantation, later known as the Two Brothers plantation, 1800-1820 (1 no.); papers relating to goods belonging to private individuals, 1771 1809 (1 no.); permits issued by the Commander to various persons for the cultivation of plots of land, 1712-1791 (1 no.).

MS inventories only are present of the government archives for the period 1828-1845. In 1828 the government of St. Martin was no longer subordinate to that of St. Eustatius but only to the General Government established at Surinam. No change was made, however, in the form of government on the island. In 1833 St. Martin received a constitution of its own, corresponding very closely with that of St. Eustatius and Saba. Supreme authority was vested in the Commander (gezaghebber), who was assisted by a Colonial Council, which replaced the former Political Council. The Court of Civil and Criminal Justice was abolished and justice was henceforth administered by the members of the Colonial Council, who, acting in this capacity, comprised what was known as the Bench. With the exception of military cases, all other civil and criminal cases, including commercial and shipping cases, were tried by this Bench. The Bench was also charged with the task of drawing up deeds of conveyance regarding real estate and mortgages.

In 1845 the General Government which had been set up in 
1828 was abolished. The Commander of Curaçao and dependent islands now came under the direct supervision of the Colonial Office, while the scope of his authority extended not only to Bonaire and Aruba but also to St. Eustatius, Saba and the Dutch zone of St. Martin.

First of all there are the a rchives of $t$ he President of the Political Council (Commander) and the Political Council (Colonial Council) (43 nos.).

The papers of the President (President van de Raad van Politie (gezaghebber)) comprise: journals, 1828-1845 (8 nos.) provided in part with alphabetical repertories; draft resolutions, 1832-1834 (1 no.); incoming papers from, and drafts of letters to, the Commissioner-General of the Netherlands West Indian Possessions, J. VAN DEN BosCH, 1828 (1 no.); incoming extracts from the journal of resolutions of the GovernorGeneral,1831-1844 (4 nos.); incoming letters and other papers from the Governor-General, 1829-1842 (1 no.); incoming letters and government instructions from the General Government (Military Office) 1828-1843 (2 nos.); incoming papers from various bodies, officials and other sources on St. Martin, 1828-1845 (2 nos.); letters received from Curaçao and St. Eustatius, 1828-1845 ( 1 no.); letters received from the French zone on St. Martin and from foreign islands in the area, 1828-1845 (1 no.); incoming petitions, 1828-1845 (1 no.); register of outgoing letters to the General Government, 1821-1845 (5 nos.); reports covering the yoare 1004, 1007/1000 and explanatory memorandum regarding the government budget estimates of St. Martin for 1845; minutes, 1835 (1844) (1 no.); registers of publications, instructions, 1818-1840 (3 nos.); register of citizens of the colony of St. Martin living outside the island, 1832 (1 no.) with alphabetical index; register of emancipated slaves who have produced their certificates of manumission at the Secretariat, 1806-1845 (1 no.); statement showing the officials present on St. Martin and their salaries, 1842 and 1844 ( 1 no.); statements regarding the appointment of and changes in, the corps of officials on St. Martin in the years 1837-1845 (1 no.); model lists and other documents used by the financial administration of the Government Store prior to 1834 (1 no.); confidential reports on the officers of the garrison on St. Martin, 18311837 (1 no.); papers regarding the hurricane of 1837 (2 nos.); papers received by the secretary of the colony, 1833 (1 no.).

The papers of the Political Council (Raad van Politie (Koloniale Raad)) comprise: proceedings of the meetings, 1832-1834 (1 no.); also the first and rough copies of the proceedings of the meetings of the Colonial Council, $1837-1845$ (2 nos.).

Other archives are those of the $\mathrm{Court}$ of $\mathrm{Civil}$ an d $\mathrm{Crim}$ i$\mathrm{n}$ a $1 \mathrm{~J} \mathrm{u} \mathrm{s} \mathrm{t} \mathrm{i} \mathrm{c} \mathrm{e,} \mathrm{1828-1834,} \mathrm{and} \mathrm{of} \mathrm{the} \mathrm{B} \mathrm{e} \mathrm{n} \mathrm{c} \mathrm{h,} \mathrm{1834-1845} \mathrm{(11} \mathrm{nos.),}$ of the C o m mis sion (after 1834, the Commissioners) for $\mathrm{P} \mathrm{u} \mathrm{n} \mathrm{y}$ A $f$ fa irs, $1828-1845$ ( 3 nos.), of the Administ rator and other accountable officials, 1816-1845 (1848) (37 nos.), and the records of the G a r ris on $\mathrm{Com} \mathrm{mander} \mathrm{(2} \mathrm{nos.)} \mathrm{and} \mathrm{of}$ the $R$ e serve ( 1 no.). 
The archives of the Court of Civil and Criminal Justice (Raad van civiele en criminele Justitie) and of the Bench (Rechtbank) contain: proceedings of the court, 1826-1834 (3 nos.); idem of the Bench, 1834 1842 (3 nos.); documents received, 1834-1836 (1 no.); court roll, 18311834 (1 no.); register of press notices regarding inheritances, etc., 1831-1835 (1840) (1 no.); documents received by the Attorney-Royal, 1835 (1 no.); declarations and other deeds regarding estates, 1828-1839 (1 no.).

The archives of the Commission (Commissioner) for Puny Affairs (College (commissarissen) tot de Kleine Zaken), for all civil cases below 150 guilders, include the proceedings of the Commission's meetings, 1836-1840 (2 nos.), sentences, 1831-1834 (1 no.).

The financial administration was in the hands of an administrator whose function was filled by the Colony Collector. The archives of this administrator and other accountable officials (administrateur en andere comptabele ambtenaren) include extracts from the Commander's resolutions received by the administrator, with appendixes, 1837-1845 (1 no.); incoming papers from the Commander, 1838 (1 no.); ledgers, 1827-1845 (7 nos.) with alphabetical indexes; accounts-current between the mother country or the General Government in Surinam and the government of St. Martin, 1830-1845 (1 no.); annual general accounts of the government administration on St. Martin for the period 18341835 (1 no.); extracts from the Commander's resolutions received by the Colony Collector, 1837-1842 (1 no.); tax register, 1821-1828 (1 no.) with index; cash books, 1828-1845 (3 nos.); alphabetical tabulated list of persons paying capitation tax, 1838 (1 no.); lists of outstanding capitation tax for the period 1832-1838 (1 no.); statement of outstanding capitation tax received during the years 1841-1842 (1 no.); register of outstanding capitation tax and other taxes, 1832-1845/1848) (1 no.) with alphabetical index; clearance register for incoming goods, 1829-1834 (1 no.); rough register of goods imported and exported, 18381842 (1 no.); registers of the clearance of incoming and outgoing vessels with accounts of the fees received in respect of them, 1829-1845 (2 nos.) ; register of import and export duties received, 1843 (1 no.).

The archives of the Administration of the Civil Servants' Pensions Fund contains the minutes of the meetings of the Administrative Council, 1819-1836 (2 nos.); papers received by the Council, 18381843 ( 1 no.); papers received by the Collector and the Paymaster 1837 (1 no.); register of receipts and expenditures, 1819-1842 (1 no.); statements and current accounts, 1819-1844 (2 nos.); inventory of the Administration of the Civil Servants' Pension Fund, 1831 (1 no.).

Among the papers originating with the auction master are a register of announcements of public auctions by the auction master, 1820 1829 (1 no.); register of announcements of forthcoming public auctions of personal property and real estate, 1831-1834 (1 no.); receipts book relating to auctions, $1816-1831$ ( 1 no.).

In the Government Store a few statements have been preserved, compiled by the financial administrator, 1837-1843 (1 no.). 
The records of the Garrison Commander (Garnizoenscommandant) contain papers received by this Commander, 1830-1836 (1 no.); statements of the garrison's stock of equipment and gunpowder, 1828; model army list of the garrison officers, 1830 (1 no.).

As regards the Reserve (landstorm), the records contain papers received by the captain and other functionaries, 1832 ( 1 no.).

The inventory of the archives of the Orphans' and Estate Court (Wees-en Boedelkamer) founded in 1793 is to be found in the 1924 Report, p. 129 (2 nos.) and MS supplement (2 nos.).

Documents present are: proceedings of the meetings, 1808-1819 ( 2 nos.) with repertories; Commissioners' minutes of the meetings of the Orphans' and Ownerless Estate Court, 1840-1845 (1 no.); inventory of the moneys, effects and securities deposited with the Court, 1840 (1 no.)

The magisterial and notarial protocols (scabinale. en notariele protocollen) include, among the former, the deeds executed in the presence of the Commander (Governor) or two Councillors. Such deeds were, for instance, deeds of conveyance, mortgage and manumission deeds. The notarial de eds executed in the presence of the secretary were referred to as secretarial deeds. After 1834 the Court of Justice on St. Martin was charged with the drawing up of deeds of conveyance in respect of real estate and mortgages. The secretary of the colony was charged, among other things, with notarial business.

The inventory of the magisterial and secretarial (notarial) protocols has been printed in the 1924 Report, p. 126-128 (99 nos.) and an MS supplement ( 3 nos.). The documents present are: protocols of magisterial deeds, 1753-1828 (26 nos.); protocol of notarial (secretarial) deeds, 1714-1827 (54 nos.). Both types of deeds are provided with tables (6 nos.). Holographic wills, 1753-1813, have also been preserved (1 no.); also a register of registered deeds, 1781-1828 (1829) (6 nos.), with table 1801-1802 (1 no.); memorandum books of secretarial business, 1785-1824 (4 nos.); protocol of magisterial deeds drawn up by the Political Council, 1829-1834 (1 no.); protocol of notarial deeds drawn up by the secretary of the colony, 1828-1829 (2 nos.).

All that has been preserved of the Ancient Civil Registration Records (Retroacta van de Burgerlijke Stand) 1808-1832 - inventory published in the 1924 Report, p. 130 ( 1 no.) - is a list of persons reported as having died to the Orphans' and Estate Court, 1808-1828 (1832) (1 no.).

In addition, a few papers are held by the General State Archives relating to the period 1828-1911, which form part of the archives still in the Netherlands West Indies. MS inventory (208 nos. Antilles: 44 nos.)

As regards Curaçao these papers include a few documents from the Governor's archives, viz., the Governor's incoming and outgoing papers, 1852-1874 (3 nos.) relating, inter alia, to the military administration 
and to a school at St. Cruz, also regulations, instructions and publications, 1856-1872 (4 nos.); death certificates, 1849-1850 (1 no.); reports regarding the condition of government buildings on Curaçao, 18561870 (1 no.); expired land concession licences, 1840-1872 (1 no.), with table of contents; lists of marriages solemnized at home, for which payment was made into the Poor Fund, 1874-1877 (1 no.); reports from the attorney-general on the receipt of fines in aid of the poor, 1848-1877 (1 no.); lists of persons who died in the first quarter of 1880 on Curaçao, Bonaire and Aruba (1 no.); contracts entered into by the Government for the carriage of Government passengers, the delivery of various articles to the hospital, etc., 1883-1885 (1 no.).

As regards the Colonial Council, proceedings of a meeting of the Council is present, 1854 ( 1 no.).

Documents of the Bench (rechtbank) and Court (hof) of Justice of Curaçao relating to a number of cases, 1850-1914 (4 nos.) are also present

Papers originating with the Commissioners for Puny Affairs and relating to a case in 1853 ( 1 no.) have also been transferred to the Netherlands.

Documents originating with the Financial Administration include: lists of names of complainants against payment of the tax on personnel and furniture, 1850-1853 (1 no.); accounting returns from the postmaster, the attorney-general, the harbour master and other officials, 18891890, 1909-1911 (1 no.); lists of slaves with evidence of enrolment recorded by the Inspectorate of the Financial Administration, 1848 (3 nos.); proceedings of the meetings, drafts of outgoing letters and other papers of the Administrative council of the Civil Servants' Pension Fund, 1846 (1 no.).

Further, the following papers are present:

From the storekeeper: a return from the Government Store on Curaçao 1856 (1 no.).

From the Military Commander: a statement of materials received and distributed at Fort Beekenburg on Curaçao, 1852 (1 no.).

From the Civil Guard and Reserve; lists of names of complainants against payment of contributions for the upkeep of the Civil Guard, 1852-1858 (1 no.); returns of weapons and clothing used by the Civil Guard of Curaçao, 1876 (1 no.).

From the Orphans' and Estate Court: a letter addressed to the Court 1852 and a deed of mortgage drawn up on its behalf, 1861 (2 nos.).

From the notarial records: a declaration relating to a plantation and a certificate of registration, 1847 (2 nos.).

A few papers relating to the period after 1845 have also been transferred from Bonaire and Aruba.

From BonAIRE: a power of attorney, 1846 (1 no.); lists accounting for medicines used and held by the medical service on Bonaire during 1846 (1 no.); list of persons deceased during the fourth quarter of 1856 on Bonaire, 1856 ( 1 no.).

From ARUBA: the Commander's journal, 1846-1848 (1 no.); papers from the Commander on Curaçao received by the Commander, 1846 1847 (1 no.) with table of contents; protocol of notarial deeds, 18461847 (1 no.) with table of contents. Furthermore, in the archives of the 
Governor of Curaçao lists are present showing the land tax (bundergelden) due for payment in Aruba from persons deceased, abroad or impecunious and of those owing land tax, 1875 (1 no.).

As regards St. Eustatius and SABA the following documents have been preserved: legal statistics of cases dealt with by the Bench and the Commission for Puny Affairs of St. Eustatius and Saba, 18531857 (1 no.); extract from the auction journal maintained on St. Eustatius with reference to the sale of landed property, 1860 (1 no.).

As regards St. Martin a return of magisterial deeds drawn up in the office of the Clerk to the Court on St. Martin, 1852 (1 no.) is present; also a statement and inventory of a deceased's estate, 1866 (1 no.); a return of import duty paid by various persons in respect of flour, peas, etc., 1849 (1 no.); notice of assessment regarding collateral death duties, 1855 (1 no.); instruction for the collector of customs on the island of St. Martin, 1863 (1 no.); certificates of manumission, 1849 (1 no.); papers received by the Commander on St. Martin, 1846-1902 (1 no.); register of writs and enforcement regarding inheritances and auctions, etc., 1831-1853 (1 no.).

In addition to the archives mentioned above, the Archives of the S t a t e s G e n e r a 1 (Staten Generaal) are of importance for supplementary research regarding the Antilles, and especially so for the period of the First West India Company, since this Company's documents are for the greater part missing.

In the States General archives resolutions covering the period 15761795 have been preserved, those from 1671 onwards being printed. The series of secret resolutions runs from 1592 to 1795. The West India files containing the correspondence between the West India Company and the States General are present for 1623 to 1795, the secret letters from 1672 to 1795 . Data concerning the Antilles are also to been found among the petitions addressed to the States General. This series covers the period 1600-1795. A collection of court case papers, 1716-1795, may also contain data relevant to the Antilles. Furthermore the States General Archives contain resolutions which deal exclusively with West Indian affairs, 1638-1695. Of the above-mentioned documents only the series of resolutions possess indexes. Papers relating to the Antilles are also to be found under the heading "West India" in the filing cabinet (loket kas), a collection of separate papers contained in the States General archives relating to the period prior to 1700 .

In view of the important role played in the general government by the Province of $\mathrm{Holland}$, the resolutions of the Provincial Assemblies of this province, in particular, may contain data concerning West Indian affairs. These resolutions are also provided with indexes.

Moreover, a small number of papers regarding the Antilles are to be found in the $\mathrm{family}$ a $\mathrm{rch}$ ives, originating with 
directors and officials of the West India Company and forming part of the first section of the General State Archives, that is to say, in the Luycx-Massis and Radermacher collections, both of which are provided with MS inventories.

Of the collections in the second section of these Archives, those of CANTZ'LAAR (an account printed in Verslagen (Reports) 1943, p. 18) and VAN HEECKEREN (MS inventory) also contain material regarding the Antilles.

The Map Collection of the General State A r c h i v e s contain a number of maps and plans of the Antilles, described by P. A. Leupe (1867) in the Foreign Maps inventory. This inventory of LEUPE's distinguishes between marine, coastal, river and land maps and groups these categories under two different headings. Both sections contain maps of the Antilles. The maps of Curaçao in the land map section are especially concerned with the fortification of the island.

The collection contains a number of general maps of Central America and the Antilles from the early and mid 17th century, inter alia maps by Hessel Gerritsz., Arnold Colom and GeRARD VAN KEULEN. The earliest separate map of the Antilles dates from 1629 . In addition various 17 th and 18 th century maps of the island of Curaçao, principally of the bays, have been preserved. Most of these maps accompany letters and papers from Curaçao to the Amsterdam Chamber of the West India Company. There are also 18th and early 19th century survey maps of the island, plans for Willemstad and Fort Amsterdam, fortification of bays, plans for military buildings and maps of some plantations. The collection also contains a few maps of Aruba, St. Eustatius, and St. Martin.

In a collection of maps from the archives of the State Secretariat is a map of Bonaire, dated 1825; also two geological charts of Curaçao and Bonaire respectively, dated 1826.

In addition to the General State Archives the $\mathrm{S} t \mathrm{tat}$ e A rchives in the Province of Zeeland can also been consulted for research regarding the Antilles, the series of resolutions in particular being important. Moreover in the Archives of the Middelburgsche Commercie Compagnie, deposited in the State Archives (inventory published by W.S. UNGER, 1951) data concerning the Antilles are to be found. 
The notarial records in the M u icipal Archives of A m sterdam will also contain documents relating to the Antilles. These notarial archives cover the period 1578-1841 and comprise over 20,000 volumes, which lack a general index. This latter fact makes any systematic search for deeds relating to the Antilles an impossibility.

Finally, mention may be made of the $\mathrm{Arch}$ ives of the Diocese (Classis) of Amsterdam which contain data regarding the West Indian Possessions, i.a, correspondence with Curaçao, a copy of a baptismal register 1659-1662, churchmember lists, etc. E. T. CoRvin has published an outline of these archives in "Ecclesiastical Records" (State of New York, Albany, 1901). No other printed inventory of them exists. 